\title{
Identification of influence factors on physical-mechanical properties, using the principal component analysis, in selecting the textile fabrics for the clothing products
}

DOI: 10.35530/IT.071.05.1754

LILIANA HRISTIAN

\section{ABSTRACT - REZUMAT}

Identification of influence factors on physical-mechanical properties, using the principal component analysis, in selecting the textile fabrics for the clothing products

The paper aims to highlight the correlations between the physical-mechanical properties of woven fabrics made of combed wool yarn with different fibrous compositions, using the Principal Component Analysis (PCA) method. Based on the information on each fabric/assortment group, it is found that four main factors were extracted: durability, comfort, production price and fabric design. The extracted components explain $92 \%$ of the variability of the twelve initial inter-correlated variables, so that we can considerably reduce the complexity of the data configured using these components, with only $8 \%$ loss of information. This technique that follows the controlled reduction of the number of variables can be used subsequently for modelling the physical-mechanical properties of the fabrics and for selecting the most suitable fabrics to satisfy the requirements of a particular field of use.

Keywords: matrix of correlations, Principal Component Analysis, factorial axis, fabrics

Identificarea factorilor de influență asupra proprietăților fizico-mecanice, utilizând analiza componentelor principale, în selecția materialelor textile pentru produsele de îmbrăcăminte

Lucrarea și-a propus să evidențieze corelațiile dintre proprietățile fizico-mecanice ale țesăturilor realizate din fire tip lână pieptănată, cu diferite compoziții fibroase, folosind metoda Analiza Componentelor Principale (PCA). Pe baza informațiilor referitoare la fiecare grup de țesături/sortiment, se constată că au fost extrași patru factori principali: durabilitatea, confortul, prețul de producție și designul țesăturilor. Componentele extrase explică 92\% din variabilitatea celor douăsprezece variabile inițiale inter-corelate, astfel încât putem reduce în mod considerabil complexitatea datelor configurate folosind aceste componente, cu doar $8 \%$ pierderi de informații. Această tehnică care urmărește reducerea controlată a numărului de variabile poate fi folosită ulterior pentru modelarea proprietăților fizico-mecanice ale țesăturilor și pentru selectarea celor mai adecvate țesături privind satisfacerea cerințelor unui anumit domeniu de întrebuințare.

Cuvinte-cheie: matricea corelațiilor, Analiza Componentelor Principale, axa factorială, țesături

\section{INTRODUCTION}

Principal Component Analysis is a method factor factor analysis - used to reduce data complexity by replacing massive data sets by smaller sets [1]. It is also used to highlight the way in which the variables are correlated with each other and to determining the (less) latent variables which are behind the (more) measured variables [2-3]. These latent variables are called factors, hence the name of the methodological factor analysis [4]. Principal Component Analysis (PCA) is a dimension-reduction tool, intensively used in different domains, such as: psychology, social sciences, production management, operational researches, development domain etc. [5, 6]. Some of the software packages, dedicated for this type of analysis, are: Statistics, SAS, SPSS. The objectives of the PCA method are: to synthesize the initial information contained in a large table; highlighting the similarities, respectively the differences between individuals; highlighting the correlations between variables; explaining the similarities, respectively the differences between individuals from the point of view of the considered variables [7, 8].

Principal components reflect both common and unique variance of the variables and may be seen as a variance-focused approach seeking to reproduce both the total variable variance with all components and the correlations. PCA is a tool for identifying the main axes of variance within a data set and allows for easy data exploration to understand the key variables in the initial data. The multiplicity and complexity of factors influencing the comfort phenomenon has resulted in numerous studies dealing with different comfort-related aspects $[9,10]$.

The state of physical comfort experienced by a wearer under a given environmental condition is greatly influenced by the tactile, thermal and moisture transport properties of the fabric. The major factors incorporating for apparel comfort are yarn structure, fabric structure and its properties, mechanical treatments, 
moisture and vapour permeability and finishing treatments [11]. During wear, moisture in clothing has been found to be the most significant factor contributing to discomfort. The presence of sweat will increase the friction between fabric and skin, trigger a clingy sensation and eventually increase the level of fatigue felt by the wearer [12]. Fabrics with excellent water absorption and transport properties have the potential to minimize the wetness sensation on skin, facilitate the evaporation of sweat and aid comfort [13]. Mechanical properties of fabric depend on the fabric structure and they are reflected in fabric weavability, which depends on the raw material and loom construction [14].

\section{EXPERIMENTAL PART}

\section{Materials and methods}

The study included four articles from four groups of worsted fabrics, of different compositions, representing the number of variables, according to table 1.

Table 1

\begin{tabular}{|c|c|c|}
\hline \multicolumn{3}{|c|}{ CODIFICATION OF WORSTED FABRICS ARTICLES } \\
\hline Group & \multicolumn{1}{|c|}{ Compozition } & Article code \\
\hline A & $100 \%$ Wool & A1, A2, A3, A4 \\
\hline B & Wool/PES 45/55 & B1, B2, B3, B4 \\
\hline C & Wool/PES/Dorlastan 45/52/3 & C1, C2, C3, C4 \\
\hline D & PES/Viscose 60/40 & D1, D2, D3, D4 \\
\hline
\end{tabular}

The percentage of chemical fibers used in blending with the wool fibers influences not only the development of the technological process but also the physical-mechanical properties of the yarns and fabrics.

The Wool/PES 45/55 blend reflects the specific properties of polyester fibers, the most important of which is the crease stability (especially for certain products: pants, skirts). Introducing more than $55 \%$ increases the roughness of the fabric.

The destination requires the delimitation of the level of the quality characteristics, by prescribed values, whose achievement is followed both by the technical project that specifies the parameters of structure, as well as by the technological process of realization. In making fabrics of the four groups were used Sirospun yarns.

In this paper, the data obtained from the quantification of the physical-mechanical properties of the fabrics were used, by standardized methods and appreciated by a series of indices determined directly on the measure equipment or by calculation. Tests on the tensile properties of fabrics were performed on the Honsfield electronic dynamometer, according to SR EN ISO 2062.

The crease recovery angle was measured, because the creasing of the fabric is an undesirable effect of temporary or permanent deformation, determined by the fibers bending and compression demands during use, processing or maintenance, according to SR EN
22313: 2013. Fabric rigidity provides information on the ability of draping, respectively to form the desired creases, whose shape and stability depend on the physical-mechanical properties of the fibers and on the fabric structure.

Among the physical properties of the fabrics, mass of the fabric, air permeability, degree of compactness, mass variation, thickness loss and porosity of the fabrics were determined by standardized methods or by calculation. The mass of the fabrics was determined according to the standard SR EN 12127:2013, which allows the comparative evaluation, essential for the use of the fabric according to the destination. The air permeability was determined in accordance with the standard EN ISO 9237:1995, which for the fabrics with the destination of clothing, must ensure the comfort state in the conditions of the activity carried out by the wearer. The degree of compactness is a complex indicator, which describes through a unitary calculation relation the fabric structure, defined by the basic parameters and auxiliaries that characterize it. The simulation of the process of friction by wearing the fabrics intended for outerwear products is carried out by a quantitative analysis of the dynamics of the pilling phenomenon by determining the following indicators: the variation of the mass and the variation of the thickness of the test fabrics. Porosity is a feature derived from the geometrical characteristics of the fabric, being dependent on the specific mass and volume of the fibrous material. For each article, the values of the physical mechanical properties were determined by standardized and processed methods in the SPSS program. The variables included in the analysis are: breaking force, $\operatorname{Pr}(\mathrm{daN})$; the mass loss at the rubbing test, $\Delta \mathrm{M}(\%)$; thickness loss at the rubbing test, $\mathrm{Sg}(\%)$; mechanical work of deformation at break, Ws (daN/m); tenacity, $\tau$ (cN/tex); the crease recovery angle, $\alpha$ (degree); elongation at break, $\varepsilon(\%)$; mass, $\mathrm{M}\left(\mathrm{g} / \mathrm{m}^{2}\right)$; air permeability, $\mathrm{Pa}$ $\left(\mathrm{m}^{3} / \mathrm{min} \cdot \mathrm{m}^{2}\right)$; degree of compactness, $\mathrm{Kt}(\%)$; rigidity, $\mathrm{R}(\mathrm{mg} \cdot \mathrm{cm})$ and porosity, $\mathrm{Pz}(\%)$. This technique aims at controlling the number of variables (columns) of the data matrix, as far as possible two, three or four. Thus, based on the information about each cluster/ fabric assortment, it is desired that instead of the nine related variables we have only two, three or four new variables called components. The purpose of the PCA is to extract the smallest number of components to recover as much of the total information contained in the initial data.

\section{RESULTS AND DISCUSSIONS}

The analysis of the behaviour of the fabrics in the wearing process shows that they are subjected to simple or repeated uniaxial or biaxial stretching.

The level of these stresses may be close to the breaking limit or may have small, insignificant values, so the designer must anticipate the behaviour to such stresses.

This can be appreciated by determining the indices deduced from the tensile strength-elongation diagram, 
such as the mechanical work of deformation at break and the tenacity of the fabrics. The hierarchy of the fabrics in the aspect of the behaviour at break is realized by the evaluation of the specific mechanical energy consumed for breaking the specimen.

The value of the quality index is influenced by: the nature of the raw material, the process and the technological parameters of processing, finishing and of the geometrical structure parameters to which the fabric is produced. The value of the degree of compactness of the fabric depends on the fineness of the yarns expressed in diameter, the density of the two yarn systems, the fabric pattern and the number of yarns of the two systems - warp and weft.

After processing the data in SPSS, applying the PCA, the following statistic results are obtained: descriptive statistics indicators (Descriptive Statistics); matrix of correlations; the calculated value of the test statistic $\chi^{2}$ and $\mathrm{KMO}$; variance variables; values and variance explained by each factorial axis; the contributions of variables to factorial axis inertia and graphical representations.

\section{Descriptive statistics indicators}

The statistical parameters calculated for each variable are shown in table 2 (Descriptive Statistics output). Analyzing the data in table 2, which contains information about each apart analyzed variable, we can see that:

- variable breaking strength, $\mathrm{Pr}$ (daN), is characterized through the mean 49.838 daN and the Std. Deviation 14.2124; maximum value of the breaking strength was obtained at the article $\mathbf{C} 3$ made of (Wool/PES/Dorlastan 45/52/3), $\mathrm{Pr}=67.3 \mathrm{daN}$, and minimum value at article $\mathbf{A} 1$ of $100 \%$ wool, $\mathrm{Pr}=$ $=23.1 \mathrm{daN}$;
- variable mass loss, $\Delta \mathrm{M}(\%)$, is characterized through the mean $1.995 \%$ and the Std. Deviation 0.7029 ; maximum value of the mass loss, was obtained at the article A2 made of (100\% Wool) $\Delta \mathrm{M}=3 \%$, and minimum value at article $\mathrm{D} 3$ of PES/Viscose 60/40, $\Delta \mathrm{M}=0.98 \%$.

The other variables are analyzed analogously. As a result of this independent analysis of each variable we can see that the most homogeneous variable is the value of the mass loss.

\section{Correlation Matrix}

The Correlation Matrix presents the values of the correlation coefficients between the variables taken by two. It is a quadratic matrix symmetric with respect to the main diagonal (equal to unit, as one variable is perfectly correlated with itself). The form of the correlation matrix is presented in table 3 after having standardized the data.

The analysis of the values of correlation matrix coefficients permits to estimate the possibility of PCA
Table 2

\begin{tabular}{|c|c|c|c|c|c|}
\hline \multicolumn{7}{|c|}{ DESCRIPTIVE STATISTICS OUTPUT } \\
\hline Variable & $\mathbf{N}$ & Minimum & Maximum & Mean & Std. Deviation \\
\hline $\mathrm{Pr}(\mathrm{daN})$ & 16 & 23.1 & 67.3 & 49.838 & 14.2124 \\
\hline$\Delta \mathrm{M}(\%)$ & 16 & 1.0 & 3.0 & 1.995 & 0.7029 \\
\hline $\mathrm{Sg}(\%)$ & 16 & 5.60 & 11.21 & 8.1956 & 1.6434 \\
\hline $\mathrm{Ws}(\mathrm{daN} / \mathrm{m})$ & 16 & 17.8 & 66.5 & 30.671 & 16.0206 \\
\hline$\tau(\mathrm{cN} / \mathrm{tex})$ & 16 & 5.8 & 17.4 & 11.975 & 3.7412 \\
\hline$\alpha(\%)$ & 16 & 142.1 & 169.7 & 159.381 & 9.7319 \\
\hline $\mathrm{Pa}\left(\mathrm{m}^{3} / \mathrm{min} \cdot \mathrm{m}^{2}\right)$ & 16 & 14.2 & 23.4 & 19.031 & 3.0366 \\
\hline $\mathrm{Kt}(\%)$ & 16 & 68.87 & 95.67 & 81.4788 & 7.1853 \\
\hline $\mathrm{Pz}(\%)$ & 16 & 58.50 & 72.12 & 65.2394 & 3.6509 \\
\hline $\mathrm{M}\left(\mathrm{g} / \mathrm{m}^{2}\right)$ & 16 & 170.3 & 231.8 & 200.931 & 16.3206 \\
\hline $\mathrm{R}(\mathrm{mg} \cdot \mathrm{cm})$ & 16 & 45.33 & 99.10 & 63.7313 & 17.7288 \\
\hline$\varepsilon(\%)$ & 16 & 16.24 & 57.80 & 34.2750 & 10.5725 \\
\hline
\end{tabular}

Table 3

\begin{tabular}{|c|c|c|c|c|c|c|c|c|c|c|c|c|c|}
\hline \multicolumn{10}{|c|}{ CORRELATION MATRIX } \\
\hline Correlation & $\begin{array}{c}\mathbf{P r} \\
(\mathbf{d a N})\end{array}$ & $\begin{array}{c}\Delta \mathbf{M} \\
(\%)\end{array}$ & $\begin{array}{c}\mathbf{S g} \\
(\%)\end{array}$ & $\begin{array}{c}\mathbf{W s} \\
(\mathbf{d a N} / \mathbf{m})\end{array}$ & $\begin{array}{c}\tau \\
(\mathbf{c N} / \mathbf{t e x})\end{array}$ & $\begin{array}{c}\alpha \\
(\mathbf{})\end{array}$ & $\begin{array}{c}\mathbf{P a} \\
\left(\mathbf{m}^{3} / \mathbf{m i n}^{\prime} \mathbf{m}^{2}\right)\end{array}$ & $\begin{array}{c}\mathbf{K t} \\
(\%)\end{array}$ & $\begin{array}{c}\mathbf{P z} \\
(\%)\end{array}$ & $\begin{array}{c}\mathbf{M} \\
\left(\mathbf{g} / \mathbf{m}^{2}\right)\end{array}$ & $\begin{array}{c}\mathbf{R} \\
(\mathbf{m g} \cdot \mathbf{c m})\end{array}$ & $\begin{array}{c}\boldsymbol{\varepsilon} \\
(\%)\end{array}$ \\
\hline $\mathrm{Pr}(\mathrm{daN})$ & 1.000 & -0.463 & -0.527 & 0.925 & 0.888 & -0.341 & 0.187 & 0.798 & 0.403 & 0.153 & 0.017 & 0.776 \\
\hline$\Delta \mathrm{M}(\%)$ & -0.463 & 1.000 & 0.393 & -0.639 & -0.773 & 0.945 & 0.212 & -0.419 & -0.309 & -0.401 & -0.423 & -0.002 \\
\hline $\mathrm{Sg}(\%)$ & -0.527 & 0.393 & 1.000 & -0.551 & -0.567 & 0.153 & -0.463 & -0.316 & -0.067 & 0.058 & 0.286 & -0.419 \\
\hline $\mathrm{Ws}(\mathrm{daN} / \mathrm{m})$ & 0.925 & -0.639 & -0.551 & 1.000 & 0.941 & -0.491 & 0.206 & 0.688 & 0.300 & 0.032 & -0.075 & 0.699 \\
\hline$\tau(\mathrm{cN} / \mathrm{tex})$ & 0.888 & -0.773 & -0.567 & 0.941 & 1.000 & -0.660 & 0.107 & 0.783 & 0.443 & 0.264 & 0.155 & 0.524 \\
\hline$\alpha(\%)$ & -0.341 & 0.945 & 0.153 & -0.491 & -0.660 & 1.000 & 0.403 & -0.342 & -0.309 & -0.498 & -0.610 & 0.136 \\
\hline $\mathrm{Pa}\left(\mathrm{m}^{3} / \mathrm{min} \cdot \mathrm{m}^{2}\right)$ & 0.187 & 0.212 & -0.463 & 0.206 & 0.107 & 0.403 & 1.000 & 0.190 & 0.149 & -0.310 & -0.792 & 0.341 \\
\hline $\mathrm{Kt}(\%)$ & 0.798 & -0.419 & -0.316 & 0.688 & 0.783 & -0.342 & 0.190 & 1.000 & 0.724 & 0.443 & 0.218 & 0.488 \\
\hline $\mathrm{Pz}(\%)$ & 0.403 & -0.309 & -0.067 & 0.300 & 0.443 & -0.309 & 0.149 & 0.724 & 1.000 & 0.629 & 0.292 & -0.032 \\
\hline $\mathrm{M}\left(\mathrm{g} / \mathrm{m}^{2}\right)$ & 0.153 & -0.401 & 0.058 & 0.032 & 0.264 & -0.498 & -0.310 & 0.443 & 0.629 & 1.000 & 0.764 & -0.296 \\
\hline $\mathrm{R}(\mathrm{mg} \cdot \mathrm{cm})$ & 0.017 & -0.423 & 0.286 & -0.075 & 0.155 & -0.610 & -0.792 & 0.218 & 0.292 & 0.764 & 1.000 & -0.353 \\
\hline$\varepsilon(\%)$ & 0.776 & -0.002 & -0.419 & 0.699 & 0.524 & 0.136 & 0.341 & 0.488 & -0.032 & -0.296 & -0.353 & 1.000 \\
\hline
\end{tabular}


application. The high values of the coefficients (higher than +0.5 and smaller than -0.5 ) show that there are significant statistical correlations (direct correlation if the coefficient value is positive, and inverse correlation if the coefficient value is negative) between the considered variables.

Analyzing the data in table 3 we can see that there are:

- significant statistical links (direct correlations) between:

- Pr (daN) and Ws (daN/m); $\tau$ (cN/tex); Kt (\%); Pz (\%); Pa ( $\left.\mathrm{m}^{3} / \mathrm{min} \cdot \mathrm{m}^{2}\right) ; \mathrm{M}\left(\mathrm{g} / \mathrm{m}^{2}\right) ; \mathrm{R}(\mathrm{mg} \cdot \mathrm{cm}) ; \varepsilon(\%)$; - $\Delta \mathrm{M}(\%)$ and $\mathrm{Sg}(\%) ; \alpha\left({ }^{\circ}\right) ; \mathrm{Pa}\left(\mathrm{m}^{3} / \mathrm{min}^{\circ} \mathrm{m}^{2}\right) ;$

- significant statistical links (reverse links) between:

- $\operatorname{Pr}(\mathrm{daN})$ and $\Delta \mathrm{M}(\%)$ and $\mathrm{Sg}(\%) ; \alpha\left(^{\circ}\right)$;

$-\Delta \mathrm{M}(\%)$ and $\operatorname{Pr}(\mathrm{daN}) ; \mathrm{Ws}(\mathrm{daN} / \mathrm{m}) ; \tau$ (cN/tex); Kt (\%); Pz (\%); M (g/m²); R (mg.cm); $\varepsilon$ (\%);

- Sg (\%) and $\operatorname{Pr}(\mathrm{daN}) ; \mathrm{Ws}(\mathrm{daN} / \mathrm{m}) ; \tau$ (cN/tex); Kt (\%); $\mathrm{Pa}\left(\mathrm{m}^{3} / \mathrm{min} \cdot \mathrm{m}^{2}\right) ; \mathrm{Pz}(\%) ; \varepsilon(\%)$.

The other variables are analyzed analogously.

In this case, PCA can be applied. A characteristic of the correlation matrix consists in the fact that the number of correlation coefficients increases very much when the number of the variables $(k)$ included in the analysis increases, irrespective of the statistic collectivity volume. The number of correlation coefficients is $k(k-1) / 2$. For the experimental data that present the values of 12 variables, the number of correlation coefficients is 66 (table 4). This significant increase of the number of correlation coefficients reveals the impossibility to interpret the correlation between the variables only by analyzing the values presented by the Correlation Matrix. The correlation matrix determinant can take values ranging within the interval $[0,1]$, showing the strength of the variables correlation. The analyzed database determinant is $\mathrm{D}=0.000$, which shows that there are strong statistic correlations between statistic variables (the values of the correlation coefficients are bigger than 0.5). In this case one can apply PCA.

The calculated value of the test statistic $\chi^{2}$ and KMO (KMO and Barlett's output)

In order to test the hypothesis of the independence between the statistic variables, the SPSS program supplies the corresponding computed values of the test statistics. Test statistics (KMO and Barlett's output) is used to test if the correlation matrix is a unit matrix, therefore if there is a statistic correlation between the statistic variables. The following statistic hypotheses are stated for these:

$\mathrm{HO}$ : independent hypothesis (correlation matrix is a unit matrix);

H1: dependent hypothesis.

To test these hypotheses, the SPSS program supplies both the computed value of the statistics $\chi^{2}=216.3$ and the value of the statistics associated with the computed test statistics (Sig $=0.000<0.05$ ), therefore the hypothesis $\mathrm{HO}$, which admitted the existence of independent variables, is rejected (table 4).
Table 4

\begin{tabular}{|c|c|c|}
\hline \multicolumn{3}{|c|}{ KMO AND BARTLETT'S TEST } \\
\hline \multicolumn{2}{|c|}{$\begin{array}{l}\text { Kaiser-Meyer-Olkin Measure of Sampling } \\
\text { Adequacy }\end{array}$} & 0.627 \\
\hline \multirow{3}{*}{$\begin{array}{l}\text { Bartlett's Test of } \\
\text { Sphericity }\end{array}$} & Approx. Chi-Square & 216.3 \\
\hline & df & 66 \\
\hline & Sig. & 0.000 \\
\hline
\end{tabular}

Therefore, one can consider with 95\% probability, that there are statistic correlations between the variables.

\section{Variables variance}

Variables standardization results in the appearance of new variables of zero-mean and variance equal to unit. The variances of statistic variables are presented in the Communalities output. Variables variance after extracting the factors is computed based on the results from the Component Matrix output (table 5). For example, for fabric tenacity it is obtained $\chi^{2}=$ $=0.981$. The small values of the variables variance after extracting the factors (see column Extraction) show that the corresponding variables can be eliminated from the analysis itself, since they are not correlated with the factorial axes.

Table 5

\begin{tabular}{|c|c|c|}
\hline \multicolumn{3}{|c|}{ COMMUNALITIES } \\
\hline Variables & Initial & Extraction \\
\hline $\mathrm{Pr}(\mathrm{daN})$ & 1.000 & 0.969 \\
\hline$\Delta \mathrm{M}(\%)$ & 1.000 & 0.971 \\
\hline $\mathrm{Sg}(\%)$ & 1.000 & 0.743 \\
\hline $\mathrm{Ws}(\mathrm{daN} / \mathrm{m})$ & 1.000 & 0.960 \\
\hline$\tau(\mathrm{cN} / \mathrm{tex})$ & 1.000 & 0.981 \\
\hline$\alpha\left({ }^{\circ}\right)$ & 1.000 & 0.949 \\
\hline $\mathrm{Pa}\left(\mathrm{m}^{3} / \mathrm{min} \cdot \mathrm{m}^{2}\right)$ & 1.000 & 0.939 \\
\hline $\mathrm{Kt}(\%)$ & 1.000 & 0.931 \\
\hline $\mathrm{Pz}(\%)$ & 1.000 & 0.906 \\
\hline $\mathrm{M}\left(\mathrm{g} / \mathrm{m}^{2}\right)$ & 1.000 & 0.851 \\
\hline $\mathrm{R}(\mathrm{mg} \cdot \mathrm{cm})$ & 1.000 & 0.936 \\
\hline$\varepsilon(\%)$ & 1.000 & 0.950 \\
\hline
\end{tabular}

Eigenvalues $\lambda_{k}$ associated to each factorial axis and variance explained by each factorial axis

The eigenvalues of the correlation matrix are presented in the Total Variance Explained (TVE), column Initial Eigen Values (table 6).

From table 6 , one can notice that the eigenvalues of the correlation matrix are:

$\lambda_{1}=5.399 ; \lambda_{2}=3.330 ; \lambda_{3}=1.389 ; \lambda_{4}=0.967$;

$\lambda_{5}=0.480 ; \lambda_{6}=0.182 ; \lambda_{7}=0.120 ; \lambda_{8}=0.063$;

$\lambda_{9}=0.038 ; \lambda_{10}=0.016 ; \lambda_{11}=0.010 ; \lambda_{12}=0.006$

The eigenvalues correspond to the inertia explained by factorial axes. Their sum represents total inertia of 


\begin{tabular}{|c|c|c|c|c|c|c|}
\hline \multicolumn{7}{|c|}{ TOTAL VARIANCE EXPLAINED } \\
\hline \multirow{2}{*}{ Component } & \multicolumn{7}{|c|}{ Initial Eigenvalues } & \multicolumn{2}{c|}{ Extraction Sums of Squared Loadings } \\
\cline { 2 - 7 } & Total & $\%$ of Variance & Cumulative \% & Total & $\%$ of Variance & Cumulative \% \\
\hline 1 & 5.399 & 44.995 & 44.995 & 5.399 & 44.995 & 44.995 \\
\hline 2 & 3.330 & 27.746 & 72.741 & 3.330 & 27.746 & 72.741 \\
\hline 3 & 1.389 & 11.575 & 84.317 & 1.389 & 11.575 & 84.317 \\
\hline 4 & 0.967 & 8.062 & 92.378 & 0.967 & 8.062 & 92.378 \\
\hline 5 & 0.480 & 3.999 & 96.377 & - & - & - \\
\hline 6 & 0.182 & 1.516 & 97.894 & - & - & - \\
\hline 7 & 0.120 & 0.999 & 98.892 & - & - & - \\
\hline 8 & 0.063 & 0.527 & 99.420 & - & - & - \\
\hline 9 & 0.038 & 0.315 & 99.735 & - & - & - \\
\hline 10 & 0.016 & 0.133 & 99.868 & - & - & - \\
\hline 11 & 0.010 & 0.081 & 99.949 & - & - & - \\
\hline 12 & 0.006 & 0.051 & 100.000 & - & - & - \\
\hline
\end{tabular}

the points cloud, equal with the number of statistic variables from the table with initial values, respectively with the sum of the elements of the correlation matrix main diagonal:

$$
\begin{aligned}
\sum_{k=1}^{k} \lambda_{k} & =5.399+3.330+1.389+0.967+0.480+ \\
& +0.182+0.120+0.063+0.038+0.016+ \\
& +0.010+0.006=12
\end{aligned}
$$

The first factorial axis explains 5.399/12 $=44.99 \%$ of the total cloud variance. The extracted components explain $92.378 \%$ of the variability of the twelve initial inter-correlated variables, so that we can considerably reduce the complexity of the data configured using these components, with only $7.622 \%$ loss of information.

The number of factorial axes which are to be interpreted in PCA was chosen in terms of two criteria:

- Kaiser's criterion which supposes the selection of that number of factorial axes for which the corresponding eigenvalues are bigger than unit. According to this criterion, one chooses three factorial axes corresponding to the eigenvalues $\left(\lambda_{1}=\right.$ 5.399; $\left.\lambda_{2}=3.330 ; \lambda_{3}=1.389\right)>1$.

- Cattel's criterion supposes eigenvalues graphical representation (Scree Plot) and pursuing the sudden inertia fall explained by these.

From the diagram shown in figure 1, three factorial axes for interpretation are chosen.

Also, the Scree Plot chart has helped to determine the optimal number of components. In general, the components on the steep slope should be removed, their contribution being superficial. It was observed that the largest decrease occurs between the penetration of the fourth and fifth components, so an easy choice is to use the first components.

These axes explain the greatest differences between statistical units in terms of the considered variables. The chosen axes are those that precede this sudden change of the slope of eigenvalues graphic (figure 1).

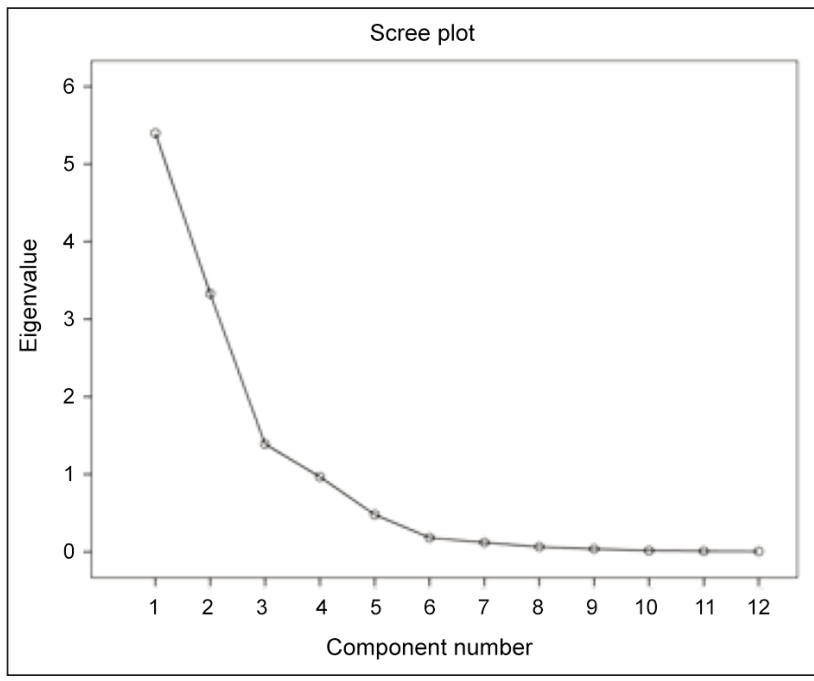

Fig. 1. Graphic representation of the correlation matrix's eigenvalues

The eigenvalues associated with the correlation matrix permit to obtain the coefficients of the variables from the linear equation of the principal axes. The eigen vectors' coordinates do not appear in the PCA results; yet they serve for the calculation of variables coordinates on the principal axes. The values from table 6 show the variables position on the factorial axes. In order to access the variables in each extracted component (table 7), the highest loading factor is selected for each variable analyzed regarding the physical-mechanical properties of combed wool fabrics, designed to make clothing products. The first component indicates that the strongest positive correlations are tenacity $(r=0.978)$, mechanical work of deformation at break $(r=0.903)$, breaking strength $(r=0.895)$ and degree of compactness $(r=$ $=0.845)$. The mechanical properties are however better represented on this axis/component and represent about $45 \%$ of the total variant and can be called "fabric durability". 
Table 7

\begin{tabular}{|c|c|c|c|c|}
\hline \multicolumn{5}{|c|}{ COMPONENT MATRIX } \\
\hline \multirow{2}{*}{ Variables } & \multicolumn{4}{|c|}{ Component } \\
\cline { 2 - 5 } & $\mathbf{1}$ & $\mathbf{2}$ & $\mathbf{3}$ & $\mathbf{4}$ \\
\hline $\mathrm{Pr}(\mathrm{daN})$ & 0.895 & 0.304 & 0.029 & 0.272 \\
\hline$\Delta \mathrm{M}(\%)$ & -0.764 & 0.368 & 0.398 & 0.305 \\
\hline $\mathrm{Sg}(\%)$ & -0.542 & -0.463 & 0.188 & 0.446 \\
\hline $\mathrm{Ws}(\mathrm{daN} / \mathrm{m})$ & 0.903 & 0.310 & -0.197 & 0.100 \\
\hline$\tau(\mathrm{cN} / \mathrm{tex})$ & 0.978 & 0.079 & -0.130 & -0.011 \\
\hline$\alpha\left({ }^{\circ}\right)$ & -0.661 & 0.578 & 0.377 & 0.191 \\
\hline $\mathrm{Pa}\left(\mathrm{m}^{3} / \mathrm{min} \cdot \mathrm{m}^{2}\right)$ & 0.085 & 0.870 & 0.366 & -0.453 \\
\hline $\mathrm{Kt}(\%)$ & 0.845 & 0.039 & 0.434 & 0.164 \\
\hline $\mathrm{Pz}(\%)$ & 0.563 & -0.258 & 0.705 & -0.157 \\
\hline $\mathrm{M}\left(\mathrm{g} / \mathrm{m}^{2}\right)$ & 0.402 & -0.713 & 0.717 & -0.082 \\
\hline $\mathrm{R}(\mathrm{mg} \cdot \mathrm{cm})$ & 0.246 & -0.905 & -0.003 & 0.238 \\
\hline$\varepsilon(\%)$ & 0.499 & 0.681 & -0.053 & 0.485 \\
\hline
\end{tabular}

The second component indicates a strong positive correlation regarding air permeability $(r=0.870)$ and a strong negative correlation regarding the rigidity of the fabrics $(r=-0.905)$. However, the physical properties are better represented on this axis and represent about $28 \%$ of the total variation, which we can call "comfort of fabrics".

The third component indicates that the highest positive correlations are given by the mass of the fabrics $(r=0.717)$, the porosity of the fabrics $(r=0.705)$ and represents about $12 \%$ of the total variation and can be called the "production price".

The fourth component indicates weaker positive correlations with thickness loss $(r=0.446)$, elongation at break $(r=0.485)$ and represents about $8 \%$ of the total variation and can be called "fabric design".

The limits of variation regarding the rigidity, the mechanical work of deformation at break, the breaking force and the degree of compactness, depend on the quality of the fibers and yarns, the density of the fabric, the type of the weave, the finishing treatments and have a special importance in appreciating the durability of a fabrics.

For the assortments of fabrics used to obtain clothing products, air permeability and flexural stiffness of the fabrics are required especially by the clothing designers who, based on common criteria, ensure the aesthetic aspect (shape, colour, design) at which some specific criteria related to ensuring the behavioural conditions from the point of view of physiological comfort is added. The mass and porosity of the fabrics are characteristics derived from the structure and blend parameters of the component yarns, which indicate the consumption of raw materials and materials, the production price, the delivery and the profit. The qualitative and quantitative analysis of the fabrics behaviour at wear by rubbing test highlights the design of the fabrics and allows the hierarchy of the assortments of fabrics made of worsted yarns, destined for the manufacture of outerwear products.
From the results obtained can be concluded that the durability, the comfort of the fabrics, the price of production and the design of the studied fabrics are influenced by the physical-mechanical properties of the raw material and by the structural characteristics of the fabrics. By applying the PCA mathematical model we obtained the controlled reduction of the number of variables (columns) of the data matrix, to four components, containing information about each group/ assortment of fabrics.

For example, the variable $\operatorname{Pr}(\mathrm{daN})$ has a positive coordinate on the first factorial axis $(r=0.895)$ and a negative coordinate on the second factorial axis $(r=0.304)$, the variable will be graphically represented in the positive values quadrants of the first factorial axis and of the second factorial axis. The variable $\mathrm{Pz}(\%)$ has a positive coordinate on the first factorial axis $(r=0.563)$ and a negative coordinate on the second factorial axis $(r=-0.258)$, the variable will be graphically represented in the positive values quadrant of the first factorial axis and in the negative values quadrant of the second factorial axis.

The high values of the variables coordinates on the factorial axes show that they are strongly correlated with the corresponding factorial axis. The variables $\tau$ (cN/tex), Ws (daN/m) and $\mathrm{Kt}(\%)$ are correlated with the first factorial axis, which shows that these variables significantly explain the differences between the statistic units (more precisely, there are significant differences between the statistic units from the standpoints of the values recorded for these variables). The variables coordinates on the factorial axes represents the coefficients of the linear equation of the correlations between the variables. For example, for the data presented in table 7 , the first axis is a new variable defined by the linear combination of the initial variables, of the form:

$$
\begin{aligned}
F_{1} & =0.895 P r-0.764 \Delta M-0.542 S g+0.903 W s+ \\
& +0.978 \tau-0.661 \alpha+0.085 P a+0.845 K t+ \\
& +0.563 P z+0.402 M+0.246 R+0.499 \varepsilon
\end{aligned}
$$

\section{Graphic representation}

The representation of the variable points on the first two factorial axes is shown in figure 2. The first factorial axis represented horizontally shows that between the variables Ws (daN/m), Kt (\%), $\operatorname{Pr}(\mathrm{daN})$, $\tau$ (cN/tex) and $\mathrm{Pz}(\%)$, there is a strong direct link and, between the variables $\alpha\left(^{\circ}\right)$ and $\mathrm{Pz}(\%)$, there is a reverse link (correlation).

The representative variables for the second factorial axis, represented vertically, are $\mathrm{Pa}\left(\mathrm{m}^{3} / \mathrm{min} \cdot \mathrm{m}^{2}\right)$ and $\mathrm{R}(\mathrm{mg} \cdot \mathrm{cm})$ between which there is a reverse link. For the interpretation of the third factorial axis, it is possible to represent the variable points in a three-dimensional space (figure 3 ). Because it is difficult to interpret the variables in the graph from figure 3 the values of the coordinates of the variables on the third factorial axis were analysed according to the values obtained in table 7 . 


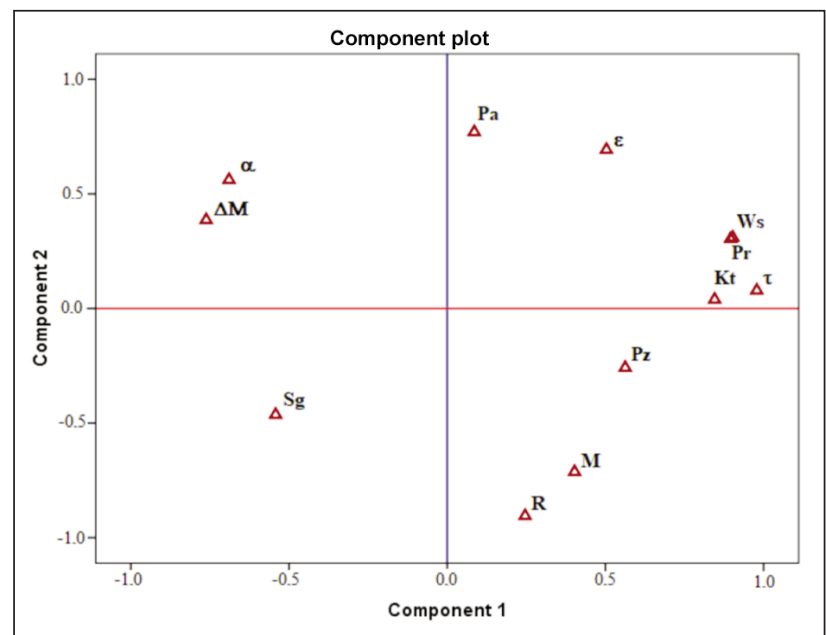

Fig. 2. Position of the variables on the first two axess

\section{CONCLUSIONS}

The paper presents the applicability of Principal Component Analysis (PCA) in the area of quantitative study of the physical-mechanical properties of wool fabrics, from different fibrous compositions and aims at selecting the most suitable fabrics for outerwear products. From the analysis, four main factors were extracted: durability, comfort, production price and fabric design. The extracted components explain $92 \%$ of the variability of the twelve inter-correlated variables, so that using these components we can

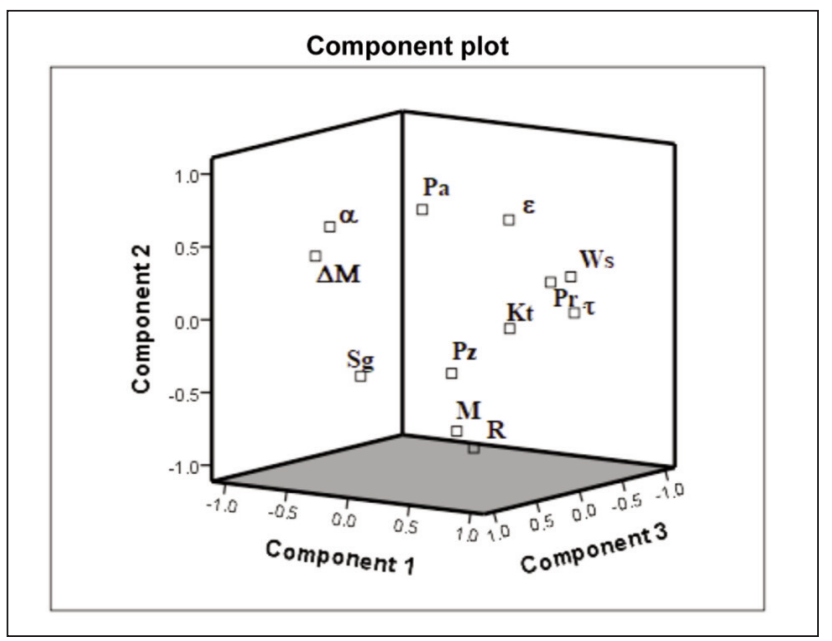

Fig. 3. Position of the variables on the three axes

considerably reduce the complexity of the configured data set, with only $8 \%$ loss of information. By using an extensive database, which correlates the characteristics/properties of fabrics, the design of fabrics can be provided by analyzing a limited number of properties. In this study, based on the correlations obtained, it was found that, through an assessment of the physical-mechanical properties, it is possible to design and manufacture the fabrics, the appropriate selection of the fibrous composition and the technological parameters for the fabrication.

\section{REFERENCES}

[1] Sass, D.A., Factor loading estimation error and stability using exploratory factor analysis, In: Education Psychology Measurement, 2010, 70, 4, 557

[2] Carr, J., Matanawi, K., Correspondence analysis for principal components transformation of multispectral and hyperspectral digital images, In: Photogrammetry Engineering and Remote Sensing, 1999, 65, 8, 909-914

[3] Hristian, L., Sandu, A.V., Manea, L.M., Tulbure, E.A., Earar, K., Analysis of the Principal Components on the Durability and Comfort Indices of the Fabrics Made of Core-coating Filament Yarns, In: Journal of Chemistry, 2015, $66,3,342-347$

[4] Hristian, L., Ostafe, M.M., Manea, L.R., Apostol, L.L., Experimental Researches on the Durability Indicators and the Physiological Comfort of Fabrics using the Principal Component Analysis (PCA) Method, In: International Conference on Innovative Research (ICIR Euroinvent), IOP Conference Series-Materials Science and Engineering, 2017, 209, 012104

[5] Dulgheriu, I., Ionescu, I., Avădanei, M., Ionesi, S.D., The Analysis of the Interaction of Working Bodies Through Studying the Cyclorama of the Sewing Machine, In: International Scientific Conference on eLearning and Software for Education (eLSE)-New Technologies and Redesigning Learning Spaces, 2019, III, 400-405

[6] Manea, L.R., Hristian, L., Ostafe, M.M., Apostol, L.L., Sandu, I., Analysis of Characterization Indexes for Worsted Fabrics Type Using Correlation Method as a Statistical Tool, In: Journal of Chemistry, 2016, 67, 9,1758-1762

[7] Tadesse, M.G., Harpa, R., Chen, R.Y., Wang, L., Nierstrasz, V., Loghin, C., Assessing the comfort of functional fabrics for smart clothing using subjective evaluation, In: Journal of Industrial Textiles, 2018, 48, 8, 1310-1326

[8] Senthilkumar, P., Kantharaj, M., Vigneswaran, C., Thermal comfort characteristics of plain woven fabrics, In: Journal of Textile Association, 2010, 71, 188-195

[9] Karaca, E., Kaharaman, N., Omeroglu, S., Becerir, B., Effects of fiber cross sectional shape and weave pattern on thermal comfort properties of polyester woven fabrics, In: Fibres and Textiles in Eastern Europe, 2012, 92, 3, 67-72

[10] Özdemir, H., Thermal comfort properties of clothing fabrics woven with polyester/cotton blend yarns, In: Textile Research Journal, 2017, 17, 2, 135-141

[11] Wang, F., Xu, G., Xu, B., Predicting the Shearing Rigidity of Woven Fabrics, In: Textile Research Journal, 2005, 75, $1,30-34$

[12] Kumpikaitè, E., Sviderskytè, A., The Influence of Woven Fabric Structure on the Woven Fabric Strength, In: Materials Science (Medžiagotyra), 2006, 12, 2, 162-166 
[13] Hristian, L., Bordeianu, D.L., lurea, P., Sandu, I., Earar, K., Study of the Tensile Properties of Materials Destined to Manufacture Protective Clothing for Firemen, In: Journal of Plastics, 2014, 51, 4, 405-409

[14] Nikolic, M., Michailovic, T., Simovic, Lj., Real Value of Weave Binding Coefficient as a Factor of Woven Fabrics Strength, In: Fibres and Textiles in Eastern Europe, 2000, 11, 74-78

Authors:

LILIANA HRISTIAN, MARIA MAGDALENA OSTAFE, IONUȚ DULGHERIU, LILIANA BUHU, ADRIAN BUHU, DANIELA NEGRU

Technical University "Gheorghe Asachi” lași, Faculty of Industrial Design and Business Management, 29 Bld. Prof.dr.doc. Dimitrie Mangeron, 700050, Iași, Romania

Corresponding author:

LILIANA HRISTIAN

e-mail: hristian@tex.tuiasi.ro 